\title{
Communities' Perception and Expectations of CSR: Implication for Corporate-Community Relations
}

\author{
Enuoh, Rebecca Oliver, Pepple, Grace Jamie, Iheanacho MaryJoan Ugboaku, Ekpe Ekpe Oyono \\ Department of Business Management, Faculty of Management Sciences, University of Calabar, Nigeria
}

\begin{abstract}
Corporate social responsibility (CSR) has over time been a subject of cumulative interest among academics and business practitioners. This paper contributes to the discourse on CSR in the context of the Nigerian oil industry with regard to corporate-community relations. It specifically constitutes an assessment of CSR initiatives by multinational corporations (MNC) operating in the Niger Delta region and their impact on the traditional livelihoods of local communities. This study examines community perceptions, expectations and seeks to interpret the relationship between the host communities and the MNCs. This paper adopts a qualitative methodological approach, it provides empirical data through the use of twenty-eight semi-structured interviews and three focus groups. This is significant given that most of the research conducted into CSR in this region have been limited to descriptive and extensive theoretical explanations. Findings from the research suggest that the relationship between the host communities and the MNCs is a very complex one. The host communities perceive the MNCs as being unfair, insensitive to the plights, neglecting their responsibilities towards them and not meeting their expectations. It therefore concludes that the negative impacts of oil extractive activities on the local communities have triggered conflict and constant dissatisfaction with the MNC. Their expectation is that of mutual positive benefit.
\end{abstract}

Keywords: Corporate Social Responsibility, Niger Delta, Multinational corporation, host communities

DOI: $10.7176 / \mathrm{EJBM} / 12-18-03$

Publication date:June 30th 2020

\subsection{Introduction}

This paper explores CSR in the context of the Nigerian oil industry with regard to corporate-community relations. The oil sector has experienced increasing pressure from the Nigerian government as well as the local people of this region in recent decades due to the dependence of the Nigerian economy on crude oil which was discovered in 1956 (Evuleocha 2005, Idemudia . The exploitation of commercial quantities of crude oil began in 1956 (Idemudia 2010). Nigeria produces approximately 2.3 million barrels of crude oil a day and has estimated oil reserves of 22.5 billion barrels mostly found in small fields in the coastal area of the Niger Delta region (Ajibade and Awomuti 2009). Most of the oil exploration and production activities take place in the Niger Delta region (NDR) consisting of nine of Nigeria's 36 states. The NDR plays a significant role in the Nigerian economy because crude oil is the main source of the country's foreign exchange earnings and federal revenue (Evuleocha 2005). Oil provides about $90 \%$ of Nigeria's foreign exchange earnings and $80 \%$ of annual federal revenue. In spite of the enormous earnings from the region's oil and gas deposits, it remains the poorest in the country (Aaron 2012). Petroleum profits have brought huge benefits to Nigeria as a whole, but very little to the local communities where the oil is being extracted (Evuleocha 2005). Lack of development, widespread poverty, feeling of marginalisation and discontent among the people of the Niger Delta have resulted in constant conflicts and crisis (Afinotan and Ojakorotu 2009).

There have been repeated agitations and sometimes violent acts by many host communities to protest concerning what was perceived as the suppression and denial of their rights to development. These tensions have affected not only the oil companies but the government as well. Instability in the region for over three decades has severely disrupted the expansion of crude oil production and invariably revenue generation (Orogun 2010). The discovery of oil in this region is often seen as good fortune to the Nigerian nation but is also seen as having serious negative impact on the people of the NDR (Idemudia and Ite 2006). The inability of the Nigerian government to meet the needs of the oil producing communities has therefore increased the expectations from the oil multinationals for greater involvement in CSR to improve their standard of living (Frynas 2005). This research therefore, focuses on the local communities' expectation of a firm to increase its positive impact and reduce its negative impact on the society in which it operates. The research is relevant in exploring how CSR undertaken by multinational oil companies can achieve desired positive impact (Ejumudo, Edo et al. 2012) in order to enhance mutual understanding and peaceful coexistence between the host communities and the oil companies. It is one of the intentions of this paper to contribute to this area of study by providing guidance on what could constitute effective corporate social responsibility.

\subsection{The Concept of Corporate Social Responsibility}

In our business world today, corporate social responsibility (CSR) has attracted worldwide attention and also seen as an important concept globally (Jamali and Mirshak 2007). The central idea of CSR is that corporate bodies have 
a responsibility to meet the needs of a wider group of its stakeholders (Clarkson 1995, Waddock, Bodwell et al. 2002) than simply its shareholders (owners). Supporters percieve CSR as an important instrument for successful business operations and as an opportunity for business to look beyond narrow economic returns and become involved in the wider social and environmental concerns (Jackson and Nelson 2004, Rudolph 2005). Unfortunately, the concept of CSR has not been homogeneously embraced because of persistent disparity of views about its potential usefulness and relevance. Therefore, scholarly definition of the concept varies due to multi-disciplinary interest giving rise to multiple interpretations (Garriga and Melé 2004, Dahlsrud 2008). The range of definitions and ideas given to the term 'CSR' appears to arise from the various perceptions held by individuals about the question of business responsibility and obligation (O'Riordan and Fairbrass 2008).

Hopkins (2003) views CSR as treating the stakeholders of the firm ethically or in a responsible manner. This idea does not limit the benefits to the firm, but rather places emphasis on the stakeholders. In line with Hopkin's views, Gössling and Vocht (2007) identify CSR as the obligation of firms to be responsible for the environment and their stakeholders in a manner that goes beyond financial goals. The stakeholder's dimension in the definitions of CSR is identified as having a very high ratio compared to the social, economic, voluntariness or environmental dimension (Dahlsrud 2008). For Bowen (1953) CSR is described as a business obligation to society that extends beyond its narrow obligation to its owners (shareholders). He argued that CSR is an obligation that arises from the impact of corporate decisions and actions on the lives of the people, and so business should be conducted in line with the objectives and values of the society. Similarly, Lea (2002) in Dahlsrud (2008) identifies CSR as business and other organisations going beyond the legal obligations to manage its impact on the environment and society. The above views are mostly centred on the impact of business on its immediate stakeholders. Considering the number of those who have a stake in the corporation, these definitions seem to be oversimplified and do not encapsulate the true nature of the relationship between corporations and their stakeholders. Dahlsrud (2008) describes CSR as a phenomenon that is socially constructed which can only be understood by the way it is defined. However, recent developments in CSR tend to disregard the definitional problem but rather emphasise the need for corporations to focus on identifying the groups to which they must fulfill their responsibility, promote a good relationship with them and establish how to engage in more effective CSR (Kim et al. 2016).

\subsection{Methodology}

The study employed two major overlapping methods of data collection; semi-structured interviews and focus groups. Face to face interviews were conducted with members of the host communities and employees of a multinational oil company (MNC). The study focused on these three host communities as they were directly affected by the activities of the multinational oil company operating in that region. A total of 28 semi-structured interviews were conducted. With a total of 24 participants from the three host communities (Mkpanak, Eket and Edo communities) and four interviews with employees of a multinational oil company. Three focus groups discussions were organised, two of the focus groups had five participants each while one of the focus groups had six participants. The participants of all the focus groups were members of the host communities. They were carefully selected to provide a mix in terms of gender and age. The data was analyzes qualitatively using thematic analysis. Themes were identified from the transcribed interview and focus group data.

\subsection{Analysis of Data from Host Communities}

From the perspective of the participants, certain programmes and projects were considered a requirement and expectation from the $\mathrm{MNC}$ in order to improve the quality of life of the host communities. These programmes were viewed as a basic requirement and part of the responsibilities of the MNC. These include a contribution to the development of the area through the provision of basic infrastructural facilities such as good roads, good water, health care services and educational facilities and recruitment of indigenes in the company. A member of the Mkpanak community said:

'...Everybody needs electricity; electricity develops a community [...], so if you give us electricity, you give us life, you give us water, and you give us life. If they can build a secondary school here it will also help our kids [...] if they can build a hospital here, we don't have a hospital, and anyone that is sick of this community goes to Eket. Most times you go to these private clinics, and there are no drugs or the drugs are very expensive that people cannot afford [...] ... give us good drinking water, give us good roads, give us clinic and schools then employ our youth. Who will complain?' (KA, 27 Oct 2017, Mkpanak)

This respondent gives an impression that the host communities are over dependent on the MNC for virtually everything they need. They believe that the MNC has come to solve all their problems which sound rather unrealistic and optimistic. It also indicates that the oil company has not done much with regards to CSR in this area that is why they are complaining. It can also be seen from the statement above that these projects are the basic requirement of any community. However, complaining about their needs could mean that what has been provided (if at all) may be insufficient. The evidence implies that the host communities expect a lot more from the MNC. It seems much of their life depends on the MNC and what they can get from them. They feel that everything they 
once owned in terms of their land and livelihood has been taken away from them and so they deserve to be compensated. There seems to be a misunderstanding between what is done in the interest of the MNC and what is done in the interest of the communities. It can equally be understood that some of the CSR projects by the MNC is seen as being done in order to boost their public image and not for the benefit of the host communities.

\subsection{Negative Effect of Oil Activities on Traditional Livelihoods}

For a corporation to be seen as being socially responsible, it is expected the corporate activities should be more beneficial to the society rather than harmful. However, the means of livelihoods of the host communities have been negatively affected by oil extraction activities of MNCs. Participants have explained that oil extractive activities of the MNCs have resulted in frequent oil spills which have had a toll on the livelihoods of the people. Their traditional livelihood activities such as farming and fishing have been seriously affected as shown by this comment from PA:

$\therefore$ now we cannot do the fishing because of the oil operation, the incessant oil spills, killing the aquatic lives and so on [...]The people realize that the fishermen, farmers and others who depend on forest and sea products as means of livelihood are seriously damaged both the land and the sea has been polluted and the forest destroyed [..] They could not fish again because if there is oil spill [company] will try to bring chemical to spray on top and the chemical will make the oil in the form of ball, and they will sink into the bed of the sea. [..] If you are fortunate enough to get fish, you cannot get the taste again because of the oil'. (PA, 27 Oct, 2017, Mkpanak)

Similarly, some participants attributed the poor catch and infertility of the soil to oil extractive activities. It is claimed that oil spill does not only affect their farmlands and the fishes in the water far from where they live but rather very close to their homes to the extent that the small gardens around their homes are also affected. However, this was disputed by the MNC operating in this region which stated that they operate off shore and so it is not possible for the host communities to complain of the oil spill on their land. This claim is captured below:

"all our warehouses are in the sea, we don't operate on land, you will not see any of our pipelines crossing anybody's water, anybody's land, anybody's farmland that is why you've not heard of oil spill [...]' (AS, 4 th Aug 2017).

It is, therefore, difficult to determine whose story to believe; whether that of the host communities or that of the MNC. The host communities are complaining on one hand of the oil that spills on their land, whereas the MNC is saying that they do not spill oil as all their facilities are off-shore. The above statement gives one the impression that the MNCs are more concerned about protecting their interest rather than solving the problem. Saying that the company's facilities are off-shore does not mean that oil spill does not occur. This statement places the company on the defence and as such indirectly freeing themselves from the blame for the oil spill. This may look like a good report for the company, but it does not in any way solve the problem. As a major multinational oil company in the state, there is a limit to what can be said to exonerate them from blame. The common concern is that oil spill occurs in this region irrespective of the facilities from which the oil spills. The host communities, therefore, seek an alternative means of survival.

$\therefore$..The discovery of oil as a means of survival in the region has now made people to dump their original means of livelihood because they see it as a fast way of making money through the oil revenue. Apart from that, the soil was no longer fertile because of the oil flow. Planting a seed where you have crude oil very close to the seed you have planted kills the seed. The oil spillage has caused most farmers to abandon their profession and seek other sources of livelihoods'. (SE, 23 Sept 2017, Eket).

The issue of the oil spill is not taken lightly by the host communities. Many participants expressed concerns about the problem of the oil spill which has been a frequent occurrence, but this seems to be ignored by the MNCs. The oil spill does not only affect their livelihoods but also their daily survival as it affects the rivers and streams where water was hitherto fetched for drinking, washing and cooking. The participant from Edo community describes one of the worst oil spills that occurred:

'..another thing is the oil spillage, to be precise, in January that was in 1998, on $12^{\text {th }}$ January 1998 there was a very serious spill from Edoho platform, the pipe just burst and that spillage was the talk of the town, [..] the entire Atlantic ocean was affected, in fact after 8 days the effect of that spill ...were affected, and people even had to scoop the crude oil. You can imagine what that will do to the aquatic organisms, the fishes [...] everything was affected. So what I'm trying to say is that oil spillage has always been on the increase...' (HU, 9 Oct 2017, Edo)

The statement above explains the magnitude of the negative effects of oil spills. The extent to which the spill could spread is unimaginable as the oil floats on water. These suggest that the issue of the oil spill has been of serious concern to members of the host communities because of the multiplier effect it tends to have on the people, their daily lives, social lives and their livelihoods.

Participants across the focus groups shared similar views on the discovery of oil and the emergence of the oil industry contributing to the hardship in their communities as a result of the negative effects on their livelihoods 
through oil spill, water pollution and gas flaring. Participants from Mkpanak were particularly unhappy about the increasing rate of oil spills off the coast of their community resulting in negative environmental impacts. They also complained of the MNC constantly denying the responsibility of such spill and refusal to pay compensation. One of the speakers states as follows:

'Before the discovery of oil, I am young but from what my grandfather told me, life was beautiful. Everybody (pause) had a hand work which they used to survive either as Potter, [..] fishermen [..] also farming because we also planted crops, so like a grown up, ...even now you take your boat and go to the sea you cannot make any catch.[..] their duty here the exploration is causing havoc to the community. They said that there would be compensation to the community, none of that compensation has been done.'(Focus group Mkpanak, 27th Oct 2017)

The extract above brings out the area of discussion on livelihood in the way that it suggests that life was different for the host communities before the discovery of oil. The people were happy and content with whatever livelihood activities they were engaged in which has been disrupted by the discovery of oil on their land. Their negative perception is also influenced by the inability of the MNC to adequately compensate them for the negative impact of oil extraction on their environment and their daily activities. However, there was a variety of opinions of participants in the focus group in Eket community. While some felt that they were better-off at that moment than before oil was discovered, others felt the situation is worse-off now. This could be due to the fact that this focus group was made up of youths only, and it seems most of the participants may not have experienced life before the arrival of the multinationals. Furthermore, participants from the focus group in Edo community believe that the provisions of social infrastructures are as important to them as the prevention of pollution on their land and water. There was some agreement between members of that group that, while they wanted a better life through modern facilities, they still needed to maintain their traditional livelihoods of farming and fishing. According to MA of Edo community;

'Our community needs a road, water, electricity, good schools and hospitals so that we can live a good life; we also need the pollution of our water and land to stop so that the people can maintain the tradition of our ancestors and also feed our families. The company cannot employ all of us so if they destroy all that we have. Where do we run to?'(Focus group Edo, $26^{\text {th }}$ August 2017)

It could be understood from this statement that the benefits they derive from the MNC are very little compared to the negative impact of the oil exploitation activities. The destruction of their traditional livelihood is not taken lightly because of its effect on their socio-cultural as well as economic lives. These suggest why the host communities depend so much on the MNC and feel frustrated over the inability of the MNC to meet up with their demands on recruitment and provision of basic social amenities. However, the disruption of traditional livelihoods may not be responsible for the relationship between one host community and another on the struggle for survival and scramble for limited resources. The conflict between one host community and another could be due to encroachment of one on another's land in search of livelihood which has subsequently resulted in conflict with the MNC. It is, therefore, pertinent to explore some past and current disputes and conflicts that have occurred within this region and their possible causes.

\subsection{Perception of MNC by Host Communities}

Considering the discussions from the previous sections and the need to clarify the nature of the relationship between the two groups, views of the host communities with regard to how they perceive the MNC were sought. It is expected that CSR should provide mutual benefit for both the corporation and the society. Drawing from the understanding of the host communities on what could be considered as socially responsible behaviour, the host communities expect fair treatment from the MNC. Though they could not specify what constitutes fair treatment, their views were in comparison to what is obtainable in other countries where oil is exploited and for that reason, they feel cheated. The host communities, therefore, perceive the MNC as treating them in an unfair manner as stated by DA:

'We are not enjoying the benefits of their activities for the past 44 years. Instead of their presence being a blessing it has rather become a curse to us. Our case should not be different from that of other countries that have crude oil. We want to feel more of their positive impact than the negative impact. This community should be seen as a small London' (DA, 24 Oct 2017, Edo)

This implies that the MNC has operated long enough to make their impact felt in the host communities. Oil corporations, having been established and operation in this region for more than four decades, the host communities might be expected to enjoy more benefits from the MNC. This is an expression of disappointment in the MNC. The statement above suggests that the host communities had high expectations from the MNC to the extent that they want their community to be as developed as other big cities in the world. Therefore anything short of this is perceived to be an unfair treatment. These feeling are related to their initial expectations from the MNC as shown in the comment by FF:

'Initially, we were happy that [company] has come to our place to improve our living a standard like we 
hear in other places. ... happy that there would be plenty of money for us to do our businesses and send our children to school. And also [..] that we will enjoy good roads, water and have beautiful buildings too, but all these dreams have not come to pass. Our hopes have been shattered because we are suffering rather than enjoying as we should. [..] We do not even have good water to drink, the water looks like urine and it is [..] not safe for drinking. Even our rivers and streams are polluted with oil; I do not feel happy at all'. (FF, 8 Aug 2017, Mkpanak)

This suggests that their expectations from the MNC went beyond improving the living standards of the people to giving them plenty of money to their businesses. They believe that MNCs in other parts of the world are living up to their expectations as regards social transformation of the cities where crude oil is discovered. However, the MNCs in their region are not doing same, and their living standards are not better than those who do not have oil on their land. This has caused the host communities to be unhappy with the MNC and is clearly stated by SE from Eket:

'...I want to say that we are not happy with (company) and the way they are treating us. There is no need of their being here and we are not feeling their impact. We expect them to do the things I had earlier mentioned (such as good road, water, schools, electricity and so on), or they should vacate our land'. (SE, 23 Sept 2017, Eket)

The statement above could be understood from a point of view of seeing their expectations as a right and an obligation that must be fulfilled by the MNC. Stating that they should provide what the communities need or vacate their land indicates the extent to which they have power over the affairs of the MNC. There is an understanding from the perspective of the host communities that the CSR activities required of them is in exchange for their land that has been used for oil exploitation. This therefore implies that there is a perceived contractual relationship between the two parties. There seems to be a general view about MNC exploiting their host communities and at the long run neglecting their responsibilities. KA expresses concern over the attitude of multinational companies towards their host communities all over the world which normally results in some sort of crisis.

'There has always been a sort of fight, noise, quarrelling and disagreement between the oil company and the host communities. The issue between an oil company and the host community [..], I don't think it is secret anymore. All over the world, it is popularly known that [..] production companies are always [..] maltreating, marginalising host communities. And the communities maybe in their demonstration of freedom or right also result in [..] problems crisis.[..] Oil companies are taking the community for granted these things are bound to continue..' (KA, 27 Oct 2017, Mkpanak)

This respondent believes that the attitude of the MNC towards them is not unusual as this may be seen to operate in MNCs across the world. He feels that the MNCs are taking the communities for granted by not doing what they ought to do. The participant below perceives the MNC as enjoying the patronage and support of the federal government which has made them neglect their responsibilities. The host communities believe that there are no strict regulations by the government on the operations of the MNCs, hence causing laxity in their responsibilities The attitude of the government, therefore, contributes to the failed expectations at the expense of the host communities. According to HU:

'...As I rightly mentioned here that at times the government has to be blamed because at times the community will like to take up arms and so on to stop production until the multinationals do what they are supposed to do but the government will come up with their plan to make sure that there is no trouble. .... By the time government will tell (company) if you don't do this or that you don't have to operate again, they have the final say to back that up. But the community on their own has to agitate, [..] the government will say wait we are going to talk on your behalf, we are going to do something about it so that has been the problem'. (HU,9 Oct 2017, Edo)

This suggests that the host communities perceive government intervention as biassed in favour of the MNC. The government is perceived as intervening only when the host communities are agitated against the MNC, but not to ensure that the right thing is done by the MNC. Therefore, their initial expectations for positive outcomes have hardly been met. Analysis so far suggests, therefore, that there is a relationship between the four themes. The negative perception of the MNC by the host community is identified as largely depending on the unmet expectations of the locals from the MNC with regard to CSR and the damaging impact of oil extractive activities on their traditional livelihoods. It is also established that the host community understands CSR as something that should generally benefit them rather than harm.

\subsection{CSR and Community Expectations/Perceptions}

From the data so far analysed, the underlying view point is that the MNC owed the community an obligation which is regarded as their responsibility towards the host communities. This study confirms the proposition that CSR remains largely contested, and its conceptualisation tends to vary across disciplines and context (Dahlsrud 2008). The divergent interests of the society on CSR has equally contributed to its multiple conceptualizations (Moir 2001). So as Dahlsrud (2008) argues, as a socially constructed concept, CSR cannot be universally defined. Based 
on the variations of views about CSR, the expectations amongst the host communities varied greatly. In response to the research question on the respondents' expectations of the host communities, some were requesting financial benefits from the company, others want employment, some expect infrastructure, while some desire total control of oil resources, others saying 'give us contracts', some 'do it yourself', another group says 'let it be anything'. These different voices and demands can be summarised to reflect the nature of the relationship.

The relationship is that of anticipated valued outcome from the MNC in exchange for the oil extracted from their land. The host communities seem to depend on the MNC for social and economic benefits which they perceive as their entitlement. George, Kuye et al. (2012) support this view by arguing that the frustration which is as a result of the inability of the multinational companies to live up to the expectations of the communities has resulted in youth restiveness in the NDR. They also state that the demand for food, clothing, shelter, employment and infrastructural facilities by the host communities is part of their quest for a better life and an act of CSR by the multinational companies. The participants also expressed concerns over the level of under-development in the area despite the number of years the oil companies have operated in the region. The expectations of the communities regarding developments in this region have largely been unmet (Idemudia and Ite 2006). Participants feel that the CSR initiative as regards improving their standard of living through the provision of basic infrastructural facilities has also not been fulfilled despite billions of dollars declared as profit by the MNC hence they are socially irresponsible (George and Kuye 2012).

Regarding unemployment, the host communities expressed displeasure with the MNC about the manner in which recruitments are often being carried out in the company without concession to the indigenes of the host communities. Residents explain that most of the recruitments are usually advertised on the internet, which many local inhabitants do not have access to and would not, therefore, be aware. In some other cases, the host communities may not even be aware of the recruitment process until it is concluded. However, the MNC assert that the communities did not possess the requisite qualifications and skills needed for such positions. Despite this reason, a contrary view is held by the communities who feel that no youth in the host communities ought to be unemployed irrespective of educational or technical status. It is expected that as part of the MNC's CSR they should be responsible for the training and recruitment of the youth of the host communities. This would be sensible or even expected because CSR entails actions being taken in response to the demands of influential stakeholders.

The environmental factors focus issues with regard to soil, water and air pollution through oil spillage and gas flaring. Most of the participants complained of frequent oil spills and gas flaring in this region. Environmental pollution as a result of the oil spill has been a regular occurrence in this region (Aghalino 2009). The host communities accuse the MNC of not changing the pipes that were installed several decades ago which often contribute to the oil spills. They feel that changing the oil pipelines would be a huge cost to the MNCs hence they kept promising to do so but have never implemented it. The host communities also accuse the federal government of negligence and lack of checks and balances by the regulatory bodies to monitor the affairs of the MNCs. As much as it is the responsibility of governments to provide infrastructure, others argue that the companies cannot be exonerated from responsibility for the destruction of their environment. However, it is the role of government to pass the necessary legislation for the protection of the environment. Ejumudo, Edo et al. (2012) assert that incorporating environmental related problems in the CSR agenda of MNCs would further reduce violence and conflicting situations.

From the discussion so far, it seems from the MNC's perspective that meeting the expectations of the host communities is not an option, but it is nevertheless a necessary evil if the MNC have to operate in a conducive and peaceful environment. The antagonistic attitude of the host communities has negatively affected the MNC and their profits. This suggests that meeting the expectations of the stakeholders could be a major determinant in meeting the expectations of the shareholders. This affirms the views of Goyder (2003) who suggests that firms should subscribe to what he calls 'conviction CSR' to ensure that they have a positive impact on the people, the natural world and the planet in addition to compliance with the law and fulfilling shareholders expectations. Similarly, it is clear that CSR cannot be effective without an inclusion of the society's values and expectations in corporations' operations as described by Griseri and Seppala (2010).

The MNCs are of the opinion that variation in community expectations makes it difficult for them to decide on the appropriate CSR initiatives to carry out in such communities. Within a community the different interest groups like the youth, women and chiefs would present different demands on what the MNC should do for the community. The opinion of the MNC as regards the CSR initiative is different as their approach is that of "one size fits all" and this does not yield positive outcomes. The use of terms such as "that is not our area of speciality" or "we are not into such projects" suggests that the company is focused on what they want to do for the communities as part of their CSR rather than what the communities are demanding. The argument here is that there should be a different approach to CSR practised by the MNC which should be based on an understanding and integration of community perceptions and needs assessment rather than company policies. As suggested by Ako, Lawrence Ogechukwu et al. (2009), the peculiarity of the area/terrain should determine ones CSR initiatives for it to be effective. Meeting such expectations would reinforce commitment on the part of the host communities and 
a cordial relationship which could also contribute to the survival of the firm (Idemudia and Ite 2006). However, the MNCs have their perspectives which are considered in the next section.

\subsection{Perception of the Host Communities by $M N C$}

Previous discussions on the data obtained from the MNC have revealed that the issue of CSR is not new to the MNC. Though it is called community investment, the MNC has enumerated the areas where they have been involved in some sort of social responsibilities which include education, sports, health care and capacity building. The MNC has also agreed that there have been issues of disputes and conflicts in the past and the present. Though the host communities use disputes as a means of compelling the MNC to listen to and solve their problems, the MNC feels that the host communities are ungrateful and expecting too much from them. This has affected the perception of the host communities and their attitude towards them as shown in the comment by NP:

'...They are always complaining about the company even if we do everything for them, they will still complain. Ehmm, see [pointing outside the office] they have road and other facilities provided for them, yet they are still complaining. They don't seem to be satisfied with whatever is done for them. Most of the problem is with regard to [company] activities here. Since [company] came here the community members always think that [..] [Company] should be sharing money to them every month; they want to transfer all their problems to us'. (NP, 11th Aug 2017, MNC)

From the statement above, the host communities are seen as having infinite demands. This implies that the host communities are never satisfied with what the MNC can provide for them. The host communities are considered to be too high and unreasonable in their expectations from the company without bothering about the role of the government. They expressed concerns over the host communities' believing that they will do everything for them and even distribute money to them. This could be argued in the sense that the host communities may be compelled to act in this manner due to the negative effects of oil extractive activities on their livelihoods. Another respondent from the MNC feels that increase in demand could lead to the company folding-up if not properly handled. MA feels that:

$\therefore$ The expectations from the communities are far higher than we can meet, and so they feel we have not done anything. No matter what the company does they will always say [company] has not done anything for us. We have tried our best, and that's it. If we are not careful [company] will fold up due to too many demands from the communities'. (MA, 10 Oct 2017, MNC)

Having performed their statutory duties of paying their taxes, the MNC feels that the host communities should be more concerned about government's obligation to them rather than place their emphasis on the oil company. The MNC feels that the taxes they pay to the government should be used in providing the host communities with their basic needs and MNCs should not be expected them to do more. This could be interpreted to mean that some of the communities' demands are not the MNC's problem but should be directed to the government.

'..The people should be more concerned about the presence of the government in providing them with social amenities rather than place all the emphasis on the company'. (MA, 10 Aug 2017, MNC)

Emphasising tax payment and the need for the host communities to channel their problems to the right quarters (government), another participant from the MNC reiterate that they are not the government and are not meant to take over the responsibilities of the government. It could be understood here that the expectations of the host communities and their demands could only be met by the government. This implies that being a business organisation, such outrageous demands could affect their profit and could cause the business to fail. AS said that: '... I keep repeating, it's very important for the message, we can't be government, we are not government, [..] government will not come and say we've not paid tax which is our obligation to the government, I mentioned that tax issue very important, it's like, it pains us when we see the kind of taxes we pay here and we end up driving on this wonderful road [being sarcastic]... much of that money goes to the government by way of petroleum profit tax[..]Then the second one is called [..] royalty tax'. (AS, 4 Aug 2017, MNC)

Arguing over the issue of responsibility and the role of the government, a participant from the host community is of the opinion that the obligation of the government should not interfere with their responsibilities as MNC, he states that:

'Leave the state government alone, the state government should do its own, [company] should also do its own. Let us leave the 13\% derivation that has nothing to do with [company], we want to benefit directly from the operations of [company]....The taxes they pay has nothing to do with their social responsibilities to the people, so let them face their own and leave government alone'. (PE, 18 Sept 2017, Eket)

It is perhaps unsurprising that the views of the host communities are quite different from those of the MNC. Whereas the MNC feel the host communities should be concerned about the role of the government in solving their problems, the host communities feel that the responsibilities of the MNC should be an additional benefit to them not minding what the government does. The host communities do not see any duplication of functions as implied by the MNC. 


\subsection{Conclusion}

This paper presents an analysis of primary data from the perspective of both the host communities and the multinational corporations. It has considered the different view-points regarding the perceptions and expectations of the host communities from the MNCs as well as that of their host communities. From the analysis it has been established that the host communities are aware of issues regarding CSR and what the MNCs are expected to do. On the other hand, the MNC assert that they have been undertaking several CSR initiatives in their host communities. However, the negative impacts of oil extractive activities on the local communities have triggered conflict and constant dissatisfaction of the host communities with the MNC which has resulted in negative reactions. The divergent views of reciprocal expectations have been likened to what is applicable in a contract hence contributory to explaining corporate-community relations in this region. Having completed the analysis of data obtained through semi-structured interviews and focus groups conducted from the host communities and the $\mathrm{MNC}$, the paper concludes that the expectations of the host communities were linked to the fact that they have provided the land on which the MOCs are drilling oil and making a profit and therefore they needed their benefits which were interpreted as good behaviour. They understood their relationship from a mutual point of view of give and take. They felt that the attitude of the MOC towards them determines their reciprocal behaviour.

\section{References}

Aaron, K. K. (2012). "New corporate social responsibility models for oil companies in Nigeria's delta region: What challenges for sustainability?" Progress in Development Studies 12(4): 259-273.

Afinotan, L. and V. Ojakorotu (2009). "The Niger Delta crisis: Issues, challenges and prospects." African journal of political science and international relations 3(5): 191-198.

Aghalino, S. (2009). "Corporate response to environmental deterioration in the oil bearing area of the Niger Delta, Nigeria, 1984-2000." Journal of sustainable development in Africa 11(2): 281-294.

Ajibade, L. and A. Awomuti (2009). "Petroleum exploitation or human exploitation? An overview of Niger Delta oil producing communities in Nigeria." African Research Review 3(1): 111-124.

Ako, R. (2012). "Re-defining corporate social responsibility (CSR) in Nigeria's post-amnesty oil industry." African Journal of Economic and Management Studies 3(1): 9-22.

Ako, R., et al. (2009). "Forging peaceful relationships between oil-companies and host-communities in Nigeria's Delta region." Journal of Enterprising Communities 3(2): 205-216.

Bowen, H. R. (1953). Social responsibility of the businessman. New York, Harper and Row.

Clarkson, M. B. E. (1995). "A stakeholder framework for analyzing and evaluating corpora." Academy of Management. The Academy of Management Review 20(1): 92.

Dahlsrud, A. (2008). "How corporate social responsibility is defined: an analysis of 37 definitions." Corporate Social Responsibility \& Environmental Management 15(1): 1-13.

Ejumudo, K., et al. (2012). "Environmental issues and corporate social responsibility(CSR) in Nigeria Niger Delta region: the need for a pragmatic approach." Journal of Social Science and Public Policy 4: 1-21.

Evuleocha, S. U. (2005). "Managing indigenous relations: Corporate social responsibility and corporate communication in a new age of activism." Corporate Communications: An International Journal 10(4): 328340.

Eweje, G. (2007). "Multinational oil companies' CSR initiatives in Nigeria." Managerial Law 49(5/6): 218-235.

Freeman, I. and A. Hasnaoui (2011). "The Meaning of Corporate Social Responsibility: The Vision of Four Nations." Journal of Business Ethics 100(3): 419-443.

Frynas, J. G. (2005). "The false developmental promise of Corporate Social Responsibility: evidence from multinational oil companies." International Affairs 81(3): 581-598.

Garriga, E. and D. Melé (2004). "Corporate Social Responsibility Theories: Mapping the Territory." Journal of Business Ethics 53(1/2): 51-71.

George, O. J. and O. L. Kuye (2012). "Corporate Social Irresponsibility (CSI) a Catalyst to the Niger Delta Crisis: The Case of Nigerian Oil Multinational Companies versus the Militants of Niger Delta Region of Nigeria." Journal of Management Research 4(2): 1-11.

George, O. J., et al. (2012). "Corporate Social Irresponsibility (CSI) a Catalyst to the Niger Delta Crisis: The Case of Nigerian Oil Multinational Companies versus the Militants of Niger Delta Region of Nigeria." Journal of Management Research 4(2): 205-215.

Gössling, T. and C. Vocht (2007). "Social Role Conceptions and CSR Policy Success." Journal of Business Ethics 74(4): 363-372.

Goyder, M. (2003). Redefining CSR: from the rhetoric of accountability to the reality of earning trust. London, Tomorrows company.

Griseri, P. and N. Seppala (2010). Business Ethics and Corporate Social Responsibility. London, Cengage Learning.

Hopkins, M. (2003). The planetary bargain: Corporate social responsibility matters. Sterling, VA, Earthscan 
publications.

Idemudia, U. (2009). "Oil Extraction and Poverty Reduction in the Niger Delta: A Critical Examination of Partnership Initiatives." Journal of Business Ethics 90: 91-116.

Idemudia, U. (2010). "Rethinking the role of corporate social responsibility in the Nigerian oil conflict: The limits of CSR." Journal of International Development 22(7): 833.

Idemudia, U. and U. E. Ite (2006). "Corporate-community relations in Nigeria's oil industry: challenges and imperatives." Corporate Social Responsibility \& Environmental Management 13(4): 194-206.

Idemudia, U. and U. E. Ite (2006). "Demystifying the Niger Delta conflict: Towards an integrated explanation." Review of African Political Economy 33(109): 391.

Jackson, I. A. and J. Nelson (2004). "Values-driven performance: Seven strategies for delivering profits with principles." Ivey Business Journal 69(2): 1-8.

Jamali, D. and R. Mirshak (2007). "Corporate Social Responsibility (CSR): Theory and Practice in a Developing Country Context." Journal of Business Ethics 72(3): 243-262.

Lea, R. (2002) Corporate Social responsibility.

Moir, L. (2001). "What do we mean by corporate social responsibility?" Corporate Governance 1(2): 16-22.

O'Riordan, L. and J. Fairbrass (2008). "Corporate Social Responsibility (CSR): Models and Theories in Stakeholder Dialogue." Journal of Business Ethics 83(4): 745-758.

Orogun, P. S. (2010). "Resource control, revenue allocation and petroleum politics in Nigeria: the Niger Delta question." GeoJournal 75(5): 459-507.

Rudolph, P. (2005). "Letter to the editor: An Adam Smith look at green regulations." The Wall street journal 6.

Trebeck, K. (2008). "Exploring the responsiveness of companies: corporate social responsibility to stakeholders." Social Responsibility Journal 4(3): 349-365.

Waddock, S. A., et al. (2002). "Responsibility: The New Business Imperative." The Academy of Management Executive (1993-2005) 16(2): 132-148.

Windsor, D. (2001). "The future of corporate social responsibility." International Journal of Organizational Analysis (1993 - 2002) 9(3): 225. 